\title{
Perspectives on FDI, Debt and Economic Growth in Emerging Markets: Evidence from China
}

\author{
Zhou Ming Matt and Wang Man Cang
}

\begin{abstract}
China has been one of the world's most important recipients of FDI and accomplished fast economic growth. This paper aims to explain the factors contributing to the inward FDI in China from 1985 to 2014 with empirical study. The elements studied include international trade, external debt ratio, GDP growth rate, CPI, technology development, labor and wage levels. It shows that debt level, international trade and lifting wages have negative effect on FDI while GDP growth rate, CPI and the abundance of Labor contribute positively to FDI. Granger causality test is performed with policy implications and suggestions presented at the end.
\end{abstract}

Index Terms-FDI, debt, economic growth, emerging market.

\section{INTRODUCTION}

During the past several decades, multinational corporations (MNCs) have increasingly invested in production and service facilities in developing countries and lower economic growth rates are associated with higher debt to GDP ratios [1]. In the meantime, developing countries adopted preferential policies to attract foreign direct investment (FDI) in the hope that FDI can help drive the economic growth and bring in advanced technology [2]. However, FDI is a double-edged sword, generating positive as well as negative spillovers. Extant studies focus on the simple issue of whether the presence of FDI contributes to the domestic economy, and have limited policy implications for developing countries. This paper is intended to fill this research gap.

During the last several decades, Chinese GDP growth performance is outstanding with the average of around 9.8 percent annually according to official data. In 1985, China's GDP was $\$ 307$ billion, 4 percent of U.S. GDP at that time. By 2014, China became the 2nd largest economy with a GDP of $\$ 10.238$ trillion, 63 percent of U.S. GDP. During the same time period, the inward FDI in China had grown by 60 times, from $\$ 1.956$ billion to $\$ 119.562$ billion; while the external debt level had been kept at a low level, the debt-to-GDP ratio was 5.16 percent in 1985 , it reached to 15.35 percent in 2001 and gradually reduced to 8.75 percent in 2014 . It had been actively debated both inside and outside China on whether this growth performance is sustainable and if China's success can be replicated elsewhere [3]. In this paper, we assess the part played by inward (and heavily export platform based) FDI and the external debt ratio, and how they relate to other

Manuscript received March 18, 2016; revised July 8, 2016.

The authors are with the Northwest University, School of Economics and Management, Xian, 710127 China (e-mail: mingzhou@stumail.nwu.edu.cn). economic factors with empirical study.

As one of the world's most important recipients of FDI, China has successfully attracted many MNCs not only because of the size and growth of its internal market and its abundance of unskilled labor, but also because foreign firms have been enticed by a wide range of policies and incentives laid out by the Chinese government, e.g. generous fiscal schemes favoring foreign-invested enterprises and the establishment of special economic zones. The use of these policies and practices are frequently justified by the existence of higher wages and international trade arising as a by-product of multinational activity. However, the presence and encouragement of foreign firms is necessary but not sufficient for generating the economic growth from FDI; the growth of domestic firms and host country financial status are also critical in determining the actual effects of FDI spillovers [4]-[7].

This paper studies the relationship of FDI and host country economic environment with the auto-regressive linear equation constructed between the inward FDI flow, international trade, GDP growth rate, debt-to-GDP ratio, CPI, domestic technology development status, labor and wage level. Furthermore, granger causality test is performed to find the granger causes for FDI, debt and others from historic data. Policy implications and suggestions are discussed with the concluding remarks presented afterwards.

\section{LITERATURE REVIEW}

About economic growth and government debt, many researchers have expressed cautionary views with high level of debt [8]. Faraglia et. suggested the composition of government debt with the market approach [9]. Orszag, Rubin and Sinai (2004) made the claim that rising debt levels could alert investors and cause interest rates to spike so that higher return can be guaranteed for investors to keep financing the debt. The interest rate spike would lead to financial market disturbance or "disarray" [10]. Manasse and Roubini (2005) have reviewed the academic literature on sovereign debt defaults and found that exposure to currency risk dominates the probability of debt default or financial crisis. Carment Reinhart and Kenneth Rogoff have analyzed economic data and financial crises across dozens of countries and hundred of years. Their work was published in the book, The Time is Different: Eight Centuries of Financial Folly (2009), and in the journal, American Economic Review, about the Growth in a Time of Debt (GITD) (2010). The conclusion is that there is no association between debt and growth at low or moderate levels of debt, while the economic growth will be negatively impacted when the threshold of 
90\% (government debt to the GDP) is crossed [11].

It has been widely accepted by many that FDI helps drive economic growth. Hymer (1960) explains direct investment can largely be explained by capital movements [12]. Papnek (1973) performs one of the first cross country empirical studies to detect that FDI can increase growth rates [13]. Blomström, Lipsey, and Zejan (1992) find that technology transfers are why FDI causes economic growth. Coe and Helpman (1995) demonstrate the possibility of and find evidence for international R\&D spillovers which De Mello (1997) claims occurs with FDI [14]. Other claimed potential beneficial effects of FDI include increased training and skill acquisition (De Mello, 1999) [15]. These results are supported by the firm-level meta-analyses of Havránek and Iršová $(2011,2012)$ which conclude that FDI has positive spillovers [16]. FDI has positive spillovers when the host country is associated with a higher level of education attainment, openness to international trade and a lower rate of population growth (Batten, 2009) [17], or income, instituional framework and human capital (Meyer and Sinani, 2009) [18].

And specific to China, evidence is shown that FDI has had a positive impact on the economic growth (Sun and Parikh, 2001; Zhang and Felmingham, 2002; Ljungwall and Tingvall, 2010) [19]-[22]. Whalley and Xin (2010) states that China's Foreign Invested Enterprises (FIEs) account for 50\% of exports and $60 \%$ of imports, and contributed over $40 \%$ of China's economic growth [23]. For the impressive growth of the Chinese economy, many reasons have been given, some are not applicable to other countries, such as the one-child policy, major cities close to important international sea routes, geographical links between China and East Asia; some are difficult to implement, such as establishing the rule of law, reducing corruption. What is left are several more general, orthodox and simpler policies such as reducing trade barriers, privatizing government businesses, and encouragement of FDI which is seen by many as crucial in trying to achieve economic growth [24]-[31].

\section{DATA AND METHODOLOGY}

The data used in this study is primarily drawn from the Wind financial database and the China Economics and Social Development Statistics database. Wind is the leading provider of financial data, information and services in China. Its data is widely cited in media news and reports, research reports and academic papers either in Chinese or in English.

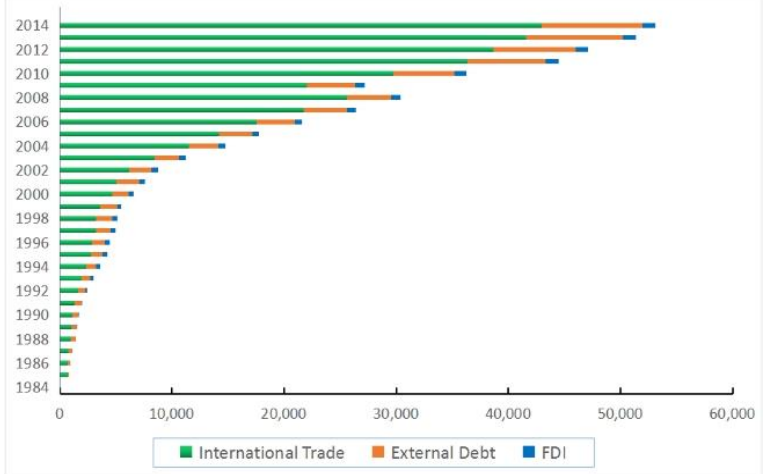

Fig. 1. International Trade, Debt and FDI in China (Unit: 100 million US\$).
Fig. 1 displays the relative growth trend of international trade, external debt and FDI from 1985 to 2014, obtained from the Wind database. The international trade data refers to the total amounts of import and export reported each year. The FDI amount is the inward foreign direct investment that is actually collected. Looking at the data, it appears that the FDI has increased along with the international and external debt over the 30 years with only two exceptions: 1999 and 2009 when the Asian financial crisis and global financial crisis occurred respectively. Foreign investors had apparently slowed down the pace in responding to the elevated risks rising from the external environment.

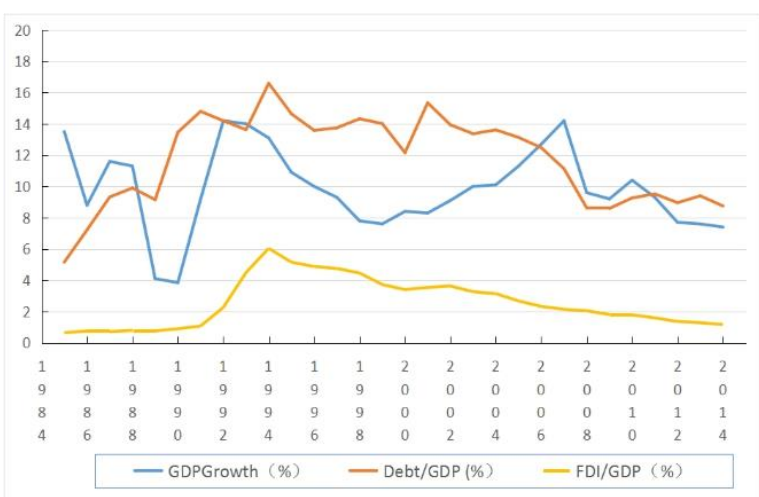

Fig. 2. GDP Growth, Debt and FDI Ratios from 1985 to 2014.

As shown in Fig. 2, China's GDP growth rate has been jumping around between $4 \%$ and $15 \%$ with the average of $9.8 \%$ since 1985 . In recent years the GDP growth rate has been stabilizing at around 7\%. The FDI-to-GDP ratio has the average of $2.5 \%$ and steadily declined since 1994 when it reached the peak of $6 \%$. During the last several years the FDI-to-GDP ratio stays at about $1.2 \%$. The external debt-to-GDP ratio ranges from $5 \%$ to $17 \%$ with the average of $11.7 \%$. In recent years the external debt-to-GDP ratio is below $10 \%$. Considering that China has the largest foreign reserve holdings, the government debt-to-GDP ratio is modest and well below that observed in most studies of OECD economies (see Wu Yanrui, 2014).

To further analyze the data, the natural logarithm system is used to model the relationship between FDI, government debt, international trade, GDP and CPI, science and technology status, local wages and unskilled labor. The following auto-regressive linear equation is constructed:

$$
\begin{aligned}
& \ln (\mathrm{FDI})=\alpha * \mathrm{DR}+\beta * \ln (\mathrm{Tr})+\gamma * \mathrm{GR} \\
& +\eta^{*} \mathrm{CPI}+\lambda * \mathrm{Pt}+\eta^{*} \mathrm{Wg}+\delta * \mathrm{~L}+\mu
\end{aligned}
$$

In which we have defined the following variables:

FDI: inward foreign direct investment with the unit of 100 million US\$;

DR: debt ratio or the external Debt-to-GDP ratio with the unit of $\%$;

Tr: the international trade or the total amounts of import and export with the unit of 100 million US\$;

GR: GDP growth rate with the unit of \%;

CPI: consumer price index with the year of 1978 as the base of 100 ;

Pt: the number of patent approved in China each year, we use it to reflect the science and technology development 
status;

$\mathrm{Wg}$ : the wage level, we use the urban resident annual income per capita with the year of 1978 as the base index of 100

L: labor, we use the reported total number of people employed in China.

\section{RESUlTS AND ANALYSIS}

\section{A. Result of Auto-regressive Linear Equation}

Eviews software is used to perform the analysis using the ordinary least square method. The result is listed as below.

$$
\begin{aligned}
& \ln (\mathrm{FDI})=-17.08 \mathrm{DR}-0.01 \ln (\mathrm{Tr})+0.08 \mathrm{GR}+ \\
& 0.008 \mathrm{CPI}+5.50 \mathrm{e}^{-7} \mathrm{Pt}-0.001 \mathrm{Wg}+4.86 \mathrm{e}^{-5} \mathrm{~L}-0.71
\end{aligned}
$$

From the R square value (0.98) and F statistics (177.16), we can see the estimated equation is pretty good. According to the calcualted regression result, increased debt level, international trade and lifting wages have negative effect on FDI whereas GDP growth rate, CPI and the abundance of Labor contributes positively to FDI. Particularly, the debt-to-GDP ratio has the largest weighted impact to the inward FDI flow.

\section{B. Unit Root Testing}

Based on the time series data above, Augmented Dickey-Fuller unit root testing (ADF) is conducted to verify the stability of the time series. Table I shows that for variable $\mathrm{Ln}(\mathrm{FDI}), \mathrm{Ln}(\mathrm{T}), \mathrm{DR}, \mathrm{GR}, \mathrm{CPI}, \mathrm{Pt}, \mathrm{Wg}$ and $\mathrm{L}$, the critical value of unit root test statistics at $1 \%, 5 \%$, and $10 \%$ significance levels are less than the value of T-statistic, and therefore the null hypothesis cannot be rejected, namely variable $\mathrm{Ln}(\mathrm{FDI}), \mathrm{Ln}(\mathrm{T}), \mathrm{DR}, \mathrm{GR}, \mathrm{CPI}, \mathrm{Pt}, \mathrm{Wg}$ and $\mathrm{L}$ are non-stationary series. For each variable in the first order difference, the critical value of unit root test statistics are greater than the value of T-statistic. Hence after the first order difference, the time series of delta $\operatorname{Ln}(\mathrm{FDI}), \mathrm{Ln}(\mathrm{T})$, DR, GR, $\mathrm{CPI}, \mathrm{Pt}, \mathrm{Wg}$ and $\mathrm{L}$ are stable with the same integration order level, which meets the co-integration test requirement.

TABLE I: ADF UNIT ROOT TESTING RESULT

\begin{tabular}{lllll}
\hline Variable & T-statistic & $1 \%$ level & $5 \%$ level & $10 \%$ level \\
\hline $\mathrm{Ln}(\mathrm{FDI})$ & 1.308130 & -2.653401 & -1.953858 & -1.609571 \\
\hline $\mathrm{rLn}(\mathrm{FDI})$ & -2.394054 & -2.650145 & -1.953381 & -1.609798 \\
\hline $\mathrm{DR}$ & -0.971244 & -3.679322 & -2.967767 & -2.622989 \\
\hline $\mathrm{r}(\mathrm{DR})$ & -4.623990 & -3.689194 & -2.971853 & -2.625121 \\
\hline $\mathrm{GR}$ & -1.125028 & -2.647120 & -1.952910 & -1.610011 \\
\hline $\mathrm{rGR}$ & -4.963861 & -2.650145 & -1.953381 & -1.609798 \\
\hline $\mathrm{Ln}(\mathrm{T})$ & -0.048969 & -3.679322 & -2.967767 & -2.622989 \\
\hline $\mathrm{rLn}(\mathrm{T})$ & -4.692393 & -3.689194 & -2.971853 & -2.625121 \\
\hline $\mathrm{CPI}$ & -1.503250 & -3.699871 & -2.976263 & -2.627420 \\
\hline $\mathrm{rCPI}$ & -3.286388 & -3.699871 & -2.976263 & -2.627420 \\
\hline $\mathrm{Pt}$ & 3.538898 & -2.669359 & -1.956406 & -1.608495 \\
\hline $\mathrm{rPt}$ & -3.242472 & -2.660720 & -1.955020 & -1.609070 \\
\hline $\mathrm{L}$ & 0.168814 & -2.674290 & -1.957204 & -1.608175 \\
\hline $\mathrm{rL}$ & -3.359837 & -2.679735 & -1.958088 & -1.607830 \\
\hline $\mathrm{Wg}$ & 2.552074 & -4.309824 & -3.574244 & -3.221728 \\
\hline $\mathrm{rWg}$ & -4.066836 & -4.323979 & -3.580623 & -3.225334 \\
\hline
\end{tabular}

Next, the residual (et) is inspected according to the estimation results and the residual time series. Table II displays the result of Augmented Dickey-Fuller unit root testing on the residual.

TABLE II: RESIDUAL TESTING RESULT

\begin{tabular}{ccccc}
\hline Residual & T-statistic & $1 \%$ level & $5 \%$ level & $10 \%$ level \\
\hline $\mathrm{e}_{\mathrm{t}}$ & -5.772282 & -2.650145 & -1.953381 & -1.609798 \\
\hline
\end{tabular}

As the T-statistic value of -5.772282 is less than the critical value of unit root test statistics at $1 \%, 5 \%$ and $10 \%$ significance levels, the residual (et) is considered as a stationary series. The results show that during the period from 1985 to 2014, Ln(FDI) has co-integration relationship with $\mathrm{Ln}(\mathrm{T})$, DR, GR, CPI, Pt, Wg and L with the co-integration vector of $(-0.01,-17.08,0.08,0.008,5.50 \mathrm{e}-07,-0.001$, $4.86 \mathrm{E}-5)$. Thus there is a long-term equilibrium relationship between Ln(FDI), Ln(T), DR, GR, CPI, Pt, Wg and L.

\section{Error Correction Model}

To study the short-term dynamic relationships between the above variables, ECM (Error Correction Model) is utilized and Table III shows the following result:

TABLE III: ECM ESTIMATION RESULT

\begin{tabular}{|c|r|r|r|r|}
\hline Variable & Coefficient & Std. Error & t-Statistic & Prob. \\
\hline $\mathrm{C}$ & -0.567654 & 0.203632 & -2.787642 & 0.0114 \\
\hline $\mathrm{D}\{\ln (\mathrm{T})\}$ & -0.020974 & 0.359545 & -0.058334 & 0.9541 \\
\hline $\mathrm{D}(\mathrm{GR})$ & 0.043970 & 0.015010 & 2.929382 & 0.0083 \\
\hline $\mathrm{D}(\mathrm{DR})$ & -9.080595 & 20.84822 & -0.435557 & 0.6678 \\
\hline $\mathrm{D}(\mathrm{CPI})$ & 0.008597 & 0.002610 & 3.293701 & 0.0036 \\
\hline $\mathrm{D}(\mathrm{Pt})$ & $3.94 \mathrm{E}-07$ & $6.43 \mathrm{E}-07$ & 0.613880 & 0.5462 \\
\hline $\mathrm{D}(\mathrm{Wg})$ & -0.001586 & 0.001653 & -0.959770 & 0.3486 \\
\hline $\mathrm{D}(\mathrm{L})$ & $-1.13 \mathrm{E}-05$ & $2.34 \mathrm{E}-05$ & -0.483048 & 0.6343 \\
\hline $\mathrm{ECM}$ & -0.834451 & 0.208629 & -3.999693 & 0.0007 \\
\hline
\end{tabular}

Hence the estimated equation is below:

$$
\begin{aligned}
& \mathrm{D}\{\ln (\mathrm{FDI})\}=-0.57-0.02 \mathrm{D}\{\ln (\mathrm{T})\}+0.04 \mathrm{D}(\mathrm{GR}) \\
& -9.1 \mathrm{D}(\mathrm{DR})+0.009 \mathrm{D}(\mathrm{CPI})+3.9 \mathrm{e}^{-7} \mathrm{D}(\mathrm{Pt})- \\
& 0.002 \mathrm{D}(\mathrm{Wg})-1.1 \mathrm{e}^{-5} \mathrm{D}(\mathrm{L})-0.83 \mathrm{ECM}(-1)
\end{aligned}
$$

From the value of -0.83 for the ECM (lag 1), it represents that when the short-term fluctuations deviated from its long-term equilibrium, a subsequent reversed (0.83) adjustments will be made to set the unbalanced state back to equilibrium.

\section{Granger Causality Test}

To further analyze the cause-effect relationship between the variables of $\mathrm{Ln}(\mathrm{FDI}), \mathrm{Ln}(\mathrm{T}), \mathrm{DR}, \mathrm{GR}, \mathrm{CPI}, \mathrm{Pt}, \mathrm{Wg}$ and $\mathrm{L}$, the Granger causality test is performed with Eviews and Table IV displays the result:

From the result, it's clear that at Lag 1 the null hypothesis is rejected. The probabilities that the external debt-to-GDP ratio doesn't granger cause $\mathrm{Ln}(\mathrm{FDI})$, and the $\ln (\mathrm{FDI})$ doesn't granger cause the external debt-to-GDP ratio are both below $1 \%$, hence the external debt-to-GDP ratio and $\mathrm{Ln}(\mathrm{FDI})$ are considered as the Granger cause for each other. This means that a good portion of the external debt is linked to the foreign direct investment at year one, hence they are the cause for each other. 
TABLE IV: GRANGER CAUSALITY TEST RESULT

\begin{tabular}{|c|c|c|c|c|c|c|}
\hline \multirow[t]{2}{*}{ Null Hypothesis: } & \multicolumn{2}{|c|}{ Lags: 1} & \multicolumn{2}{|c|}{ Lags: 2} & \multicolumn{2}{|r|}{ Lags: 3} \\
\hline & F-Stat. & Prob. & F-Stat. & Prob & F-Stat. & Prob. \\
\hline DR does not Granger Cause ln(FDI) & 8.513 & 0.0072 & 1.315 & 0.288 & 1.010 & 0.409 \\
\hline $\ln ($ FDI) does not Granger Cause DR & 38.292 & $2.0 \mathrm{E}-6$ & 19.58 & $1.0 \mathrm{E}-5$ & 8.016 & 0.001 \\
\hline GR does not Granger Cause $\ln (\mathrm{FDI})$ & 3.590 & 0.069 & 16.94 & 3.E-05 & 6.571 & 0.003 \\
\hline $\ln (\mathrm{FDI})$ does not Granger Cause GR & 0.002 & 0.966 & 0.150 & 0.861 & 1.576 & 0.226 \\
\hline CPI does not Granger Cause $\ln (\mathrm{FDI})$ & 1.4377 & 0.2413 & 1.4085 & 0.2648 & 0.2122 & 0.8868 \\
\hline $\ln (\mathrm{FDI})$ does not Granger Cause CPI & 16.994 & 0.0003 & 6.3775 & 0.0063 & 3.2801 & 0.0422 \\
\hline CPI does not Granger Cause DR & 14.708 & 0.0007 & 5.9649 & 0.0082 & 2.3079 & 0.1074 \\
\hline DR does not Granger Cause CPI & 0.8655 & 0.3608 & 0.4960 & 0.6153 & 0.4182 & 0.7419 \\
\hline GR does not Granger Cause DR & 4.7487 & 0.0386 & 4.7706 & 0.0185 & 4.3216 & 0.0167 \\
\hline DR does not Granger Cause GR & 0.7776 & 0.3859 & 0.0540 & 0.9476 & 2.1694 & 0.1234 \\
\hline Wg does not Granger Cause $\ln (\mathrm{T})$ & 1.5919 & 0.2183 & 4.4861 & 0.0226 & 3.9859 & 0.0224 \\
\hline $\ln (\mathrm{T})$ does not Granger Cause $\mathrm{Wg}$ & 9.1276 & 0.0056 & 5.5224 & 0.0110 & 3.7713 & 0.0270 \\
\hline
\end{tabular}

Similarly, we find that the GDP growth rate is the granger cause for $\operatorname{Ln}(\mathrm{FDI})$ at lag 2 and 3 . When the foreign investors see the increase of output from the last year, there's strong motive for them to invest more in subsequent years. However, the analysis finds that $\mathrm{Ln}(\mathrm{FDI})$ is not the granger cause for the GDP growth rate.

It's also interesting to find that $\mathrm{Ln}(\mathrm{FDI})$ is the granger cause for CPI at lag 1,2 and 3. When the foreign investment comes in, it's been exchanged into the Chinese currency, which causes more RMB issued. That leads to the inflation and increase of CPI.

In addition, it shows that GDP growth rate is the granger cause for the external debt-to-GDP ratio at lag 1,2 and 3 . With the economic development and GDP growth achieved, the external debt would be easier to obtain. The reverse effect does not exist according to the result above.

Finally, $\operatorname{Ln}(\mathrm{T})$ is the granger cause for the wage at lag 1, 2 and 3 . With the development of international trade activities, MNCs have hired more and more employees who usually get better pay than in domestic firms. To compete with MNCs, domestic firms will raise the wages, thus the urban resident income level is lifted as a whole.

\section{CONCLUDING REMARKS}

Over the past several decades China has been one of the world's most important recipients of FDI. A widely held belief is that FDI is an important factor for the outstanding economic growth in China. And the generous fiscal schemes and incentives favoring foreign-invested enterprises laid out by Chinese government seemingly provide evidence for this position. Another common view is that the developing country should favor increased debt level for more economic growth. Our overall findings dispute these views.
Based on the Economics and Social Development data for the last three decades, the FDI and debt issues are analyzed and the auto-regressive linear equation is constructed to study the relationship between inward FDI flow, external debt level, GDP growth rate, CPI, technology development status, local technology status, labor and wage level. Granger causality test is performed to find the granger cause for FDI, Debt-to-GDP ratio, economic growth and wages.

From the above analysis, we find $\operatorname{Ln}(\mathrm{FDI})$ has co-integration relationship with $\mathrm{Ln}(\mathrm{T})$, DR, GR, CPI, Pt, Wg and $\mathrm{L}$ with the co-integration vector of $(-0.01,-17.08,0.08$, $0.008,5.50 \mathrm{e}-07,-0.001,4.86 \mathrm{E}-5)$. There is a long-term equilibrium relationship between FDI, international trade, debt-to-GDP ratio, GDP growth rate, CPI, number of patent approved, wage level and labors. When the short-term fluctuations deviated from its long-term equilibrium, a subsequent reversed (0.83) adjustments will be made to set the unbalanced state back to equilibrium.

Further analysis shows that the increase of FDI flow and GDP have led to the increase of external debt level. This implies that the government intents to raise more debt when a higher GDP growth rate or FDI goal is achieved, or more external debt is obtained when the foreign investors see a better GDP growth rate or increase the investment. This explains that the host country government have leveraged the external debt for more economic growth. On the other hand, the increase of external debt-to-GDP ratio has negative impact for the inward FDI flow according to the regression result based on the three decades data in China. Foreign investors are more likely to invest when they see a relatively low debt level and hence become more confident with the financial environment in host country.

It's also interesting to find that the CPI rise has been a by-product of inward FDI flow. The hot money flowing into 
the host country will cause inflation, and the increase of CPI has a negative impact on the external debt level. When CPI increases, the cost goes up for host country government to borrow and carry on the development projects, thus the government tends to raise less debts.

Our study suggests that rising debt-to-GDP ratio can significantly affect the growth of FDI. Furthermore, FDI and economic growth tend to cause inflation, rising CPI and host country debt-to-GDP ratio. This suggests that transplanting Chinese style policies that favour FDI to other developing countries to further their development on the basis of this belief will likely cause similar inflation impact on their economy. Developing countries should monitor their souverign debt status closely as maintaining the modest debt level will be beneficial for the economic growth.

\section{ACKNOWLEDGMENT}

The authors would like to thank for the valuable suggestions received from Prof. Ali Kutan in Southern Illinois University, and Dr. Wang Xinmei from the China Academy of Social Science.

Finally we'd like to pay tribute to the editors and anonymous reviewers for their professional input.

\section{REFERENCES}

[1] A. Afonso and J. Jalles, "Growth and productivity: The role of government debt," International Review of Economics and Finance, vol. 25, pp. 384-407, 2013.

[2] L. Alfaro, A. Chanda, S. Kalemli-Ozcan, and S. Sayek, "FDI and economic growth: The role of local financial markets," Journal of International Economics, Elsevier, vol. 64, no. 1, pp. 89-112, October 2004.

[3] A. Banerjee, "FDI in China and its economic impact," World Review of Entrepreneurship, Management and Sustainable Development (WREMSD), vol. 2, no. 1/2, 2006.

[4] E. Borensztein, J. Gregorio, and J-W Lee, "How does foreign direct investment affect economic growth?" Journal of International Economics, Elsevier, vol. 45, no. 1, pp. 115-135, June 1998.

[5] C. Zhao and J. Du, "causality between fdi and economic growth in china,” Chinese Economy, M. E. Sharpe, Inc., vol. 40, no. 6, pp. 68-82, November 2007.

[6] C. Ljungwall and P. Tingvall, "Is China different? A meta-analysis of the effects of foreign direct investment on domestic firms," Journal of Chinese Economic and Business Studies, vol. 8, no. 4, pp. 353-371, 2010.

[7] J. Durham and J. Benson, "Absorptive capacity and the effects of foreign direct investment and equity foreign portfolio investment on economic growth," European Economic Review, Elsevier, vol. 48, no. 2, pp. 285-306, April, 2004.

[8] P. A. Diamond, "National debt in a neoclassical growth model," American Economic Review, vol. 55, no. 5, pp. 1126-1150, 1965.

[9] E. Faraglia, A. Marcet, and A. Scott, "in search of a theory of debt management," Journal of Monetary Economics, Elsevier, vol. 57, no. 7, pp. 821-836, October 2010.

[10] R. Rubin, P. R. Orszag, and A. Sinai, "Sustained budget deficits: longer-run U.S. economic performance and the risk of financial and fiscal disarray," in Proc. Allied Social Science Associations Annual Meetings, San Diego, CA, January 4, 2004.

[11] C. M. Reinhart and K. Rogeoff, "Growth in a time of debt," American Economic Review, vol. 100, no. 2, pp. 573 - 578, 2010.

[12] S. H. Hymer, "The international operations of national firms: A study of direct foreign investment," Cambridge, MA: The MIT Press, 1976.

[13] G. Papanek, "Aid, foreign private investment, savings, and growth in less developed countries," Journal of Political Economy, University of Chicago Press, vol. 81, no. 1, pp. 120-30, Jan.-Feb, 1973.

[14] L. Mello, "Foreign direct investment in developing countries and growth: A selective survey," Journal of Development Studies, vol. 34, no. 1, pp. 1-34, 1997.
[15] L. Mello, "Foreign direct investment-led growth: Evidence from time series and panel data," Oxford Economic Papers, Oxford University Press, vol. 51, no. 1, pp. 133-151, January 1999.

[16] T. Havranek and Z. Irsova, "Survey article: Publication bias in the literature on foreign direct investment spillovers," Journal of Development Studies, vol. 48, no. 10, pp. 1375-1396, October 2012.

[17] J. Batten and X. V. Vo, "An analysis of the relationship between foreign direct investment and economic growth," Applied Economics, Taylor and Francis Journals, vol. 41, no. 13, pp. 1621-1641, 2009.

[18] K. E. Meyer and E. Sinani, "When and where does foreign direct investment generate positive spillovers? A meta-analysis," Journal of International Business Studies, vol. 40, no. 7, pp. 1075-1094, 2009.

[19] J. Shan, "A VAR approach to the economics of FDI in China," Applied Economics, vol. 34, issue 7, pp. 885-893, 2002.

[20] K. H. Zhang, "How does foreign direct investment affect economic growth in China?" The Economics of Transition, The European Bank for Reconstruction and Development, vol. 9, no. 3, pp. 679-693, November 2001

[21] W. S. Kim, E. Lyn, and E. Zychowicz, "Is the source of FDI important to emerging market economies? Evidence from Japanese and U.S. FDI," Multinational Finance Journal, Issue 7, pp. 107-130, 2003.

[22] Q. Liu, R. Lu, and C. Zhang, "The labor market effect of foreign acquisitions: Evidence from Chinese manufacturing firms," China Economic Review, vol. 32, pp. 110-120, 2015.

[23] J. Whalley and X. Xin, "China's FDI and non-FDI economies and the sustainability of future high Chinese growth," China Economic Review, vol. 21, no. 1, pp. 123-135, 2010.

[24] J. Ran, J. Voon, and G. Li, "How does FDI affect China? Evidence from industries and provinces," Journal of Comparative Economics, Elsevier, vol. 35, no. 4, pp. 774-799, December 2007.

[25] X. Tian, "Accounting for sources of FDI technology spillovers: Evidence from China," Journal of International Business Studies, vol. 38, no. 1, pp. 147-159, 2007.

[26] X. Tian, S. Lin, and V. Lo, "Foreign direct investment and economic performance in transition economies: Evidence from China," Post-Communist Economies, Taylor and Francis Journals, vol. 16, no. 4, pp. 497-510, 2004.

[27] A. Y. Yalta, "Revisiting the FDI-led growth hypothesis: The case of China," Economic Modelling, Elsevier, vol. 31, no. C, pp. 335-343, 2013.

[28] Y. Huang, "How did China take off?" Journal of Economic Perspectives, American Economic Association, vol. 26, no. 4, pp. 147-70, Fall 2012.

[29] K. H. Zhang, "How does Foreign direct investment affect industrial competitiveness? Evidence from China," China Economic Review, vol. 30, no. 1, pp. 530-539, 2014.

[30] J. Zhou and M. C. Latorre, "The impact of FDI on the production networks between China and East Asia and the role of the U.S. and ROW as final markets," Global Economic Review: Perspectives on East Asian Economies and Industries, vol. 43, no. 3, pp. 285-314, 2014.

[31] N. Chaudhry, A. Mehmood, and M. Mehmood, "Empirical relationship between foreign direct investment and economic growth: An ARDL co-integration approach for China," China Finance Review International, Emerald Group Publishing, vol. 3, no. 1, pp. 26-41, February, 2013.

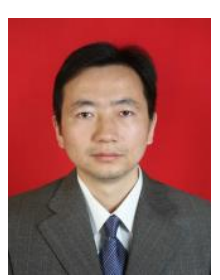

Zhou Ming Matt was born in Xi'an, China. He has earned the B.S. degree from Tsinghua University (Beijing, China), M.S. degree from University of Cincinnati (Ohio, USA) and MBA degree in finance from Hofstra University (New York, USA). He is the Ph.D. candidate at Northwest University, School of Economics and Management. Mr. Zhou has an interest in the field of finance, banking and fiscal policies.

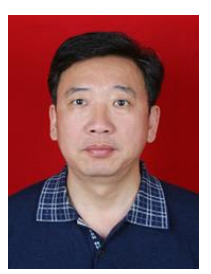

Wang Man Cang was born in Heyang, China. He received his $\mathrm{Ph} . \mathrm{D}$ degree from Xi'an Jiao Tong University in 2000. His research interests include financial development and economic growth, corporate governance, financial market and international finance. $\mathrm{He}$ is a Professor at North West University and the head of the Department of Finance in the School of Economic and Management. 